Received: July 13,2017

Accepted: July 23, 2017

Published: August 14,2017

\section{Interaction of Cholera Toxin B Subunit with Intestinal Epithelial Cells}

Elena V. Navolotskaya ${ }^{1, *}$,Vladimir B. Sadovnikov ${ }^{1}$,Valery M. Lipkin ${ }^{2}$, and Vladimir P. Zav'yalov $^{3}$

${ }^{1}$ Branch of Shemyakin and Ovchinnikov Institute of Bioorganic Chemistry, Science Avenue, 6, Pushchino, Moscow Region, 142290 Russian Federation.

${ }^{2}$ Shemyakin and Ovchinnikov Institute of Bioorganic Chemistry, Miklukho-Maklaya street, 16/10, Moscow, GSP-7, 117997, Russian Federatiok

${ }^{3}$ University of Turku, Vatselankatu 2, 1st floor, Turku, 20500 Finland

*Corresponding author: Dr. Elena V. Navolotskaya, Branch of Shemyakin and Ovchinnikov Institute of Bioorganic Chemistry, Science Avenue, 6, Pushchino, Moscow Region, 142290 Russian Federation. Fax: +7(4967)79-05-27; E-mail: mark.navolotskaya@bibch.ru

\section{Abstract}

We have prepared ${ }^{125}$ I-labeled cholera toxin $\mathrm{B}$ subunit ( ${ }^{125}$ I-labeled CT-B, a specific activity of 98 $\mathrm{Ci} / \mathrm{mmol}$ ), and found that its binding to rat IEC-6 intestinal epithelial cells was high-affinity $\left(\mathrm{K}_{d} 3.7 \mathrm{~nm}\right)$. The binding of labeled protein was completely inhibited by unlabeled thymosin- $\alpha_{1}$ (TM- $\left.\alpha_{1}\right)$, interferon- $\alpha_{2}$ (IFN$\alpha_{2}$ ), and the synthetic peptide LKEKK that corresponds to residues 16-20 in TM- $\alpha_{1}$ and 131-135 in IFN- $\alpha_{2}\left(\mathrm{~K}_{i}\right.$ 1.5, 1.0 and $2.0 \mathrm{HM}$, respectively), but was not inhibited by the synthetic peptide KKEKL with inverted amino acid sequence $\left(\mathrm{K}_{i}>10 \mu \mathrm{m}\right)$. Thus, TM- $\alpha_{1}$, IFN- $\alpha_{2}$, and the peptide: LKEKK bind with high affinity and specificity to CT-B receptor on riec- 6 cells. It was found that CT-B and the peptide: LKEKK at concentrations of 10 $1000 \mathrm{~nm}$ increased in a dose-dependent manner the nitric oxide production and the soluble guanylate cyclase activity in the cells.

\section{Keywords} line

Protein: Peptide; Receptor; Cholera toxin B subunit; IEC-6 cell

\section{Abbreviations}

AC: adenylate cyclase, CT-B: cholera toxin B subunit, GC: guanylate cyclase, IFN- $\alpha$ : interferon- $\alpha$, Kd: equilibrium dissociation constant, $\mathrm{K}_{i}$ : equilibrium inhibition constant, NOC-18: 2:2'-(hydroxynitrosohydrazino)bis-ethamine, rIEC-6: rat intestinal epithelial cell line, SEM: standard error of the mean, TM- $\alpha_{1}$ : thymosin- $\alpha_{1}$.

\section{Introduction}

More than two decades ago octapeptide LKEKKYSP corresponding to the sequence $131-138$ of human interferon- $\alpha_{1}$ (IFN$\alpha_{2}$ ) capable of high affinity binding to murine thymocytes and human fibroblasts [32] was obtained. [31] Binding of labeled octapeptide was competitively inhibited by unlabeled IFN- $\alpha_{2}$, thymosin- $\alpha_{1}$ (TM- $\left.\alpha_{1}\right)$ and cholera toxin B-subunit (CT-B). Comparison of amino acid sequences of the octapeptide and TM- $\alpha_{1}$ showed that they contain the same LKEKK fragment corresponding to the sequence 16-20 TM- $\alpha_{1}$ and 131-135 IFN- $\alpha_{2}$ (Figure 1). We suggested that this fragment may be involved in the binding of TM- $\alpha_{1}$ and IFN- $\alpha_{2}$ with a common receptor and synthetic peptide LKEKK may also have the same ability.

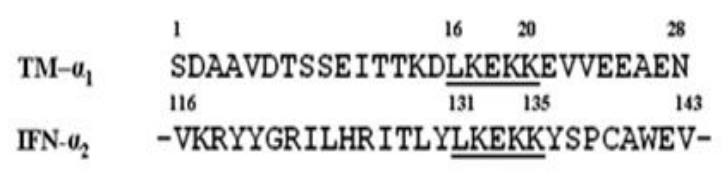

Figure 1: Comparison of amino acid sequences of TM- $\alpha_{1}$ and IFN- $\alpha_{2}$. The numbers of the amino acid residues are marked with numerals. Sequence of peptide LKEKK is underlined.

Recently we have synthesized the peptide LKEKK and found that $[3 \mathrm{H}]$ LKEKK binds with high affinity to donor blood T lymphocytes and rat intestine epithelial cell membranes [16,17]. Treatment of cells and membranes with proteases did not affect $\left[{ }^{3} \mathrm{H}\right]$ LKEKK binding, suggesting the non-protein nature of the peptide receptor. The binding was completely inhibited by TM- 
Table 1 Main characteristics of the synthesized peptides

\begin{tabular}{|c|l|l|l|}
\hline Peptide & $\begin{array}{l}\text { Purity, } \\
\%\end{array}$ & $\begin{array}{l}\text { Amino acid } \\
\text { analysis } \\
\text { data }\end{array}$ & $\begin{array}{l}\text { Molecular } \\
\text { mass, D }\end{array}$ \\
\hline LKEKK & $>98$ & $\begin{array}{c}\text { Glu 1.09 (1), Leu } \\
1.00(1), \text { Lys 3.27 (3) }\end{array}$ & $\begin{array}{c}\text { 645.2 } \\
\text { (calculated value } \\
\text { ? 644.87) }\end{array}$ \\
\hline KKEKL & $>97$ & $\begin{array}{c}\text { Glu 1.12 (1), Leu } \\
1.03(1), \text { Lys 3.32 (3) }\end{array}$ & 648.6 (644.87) \\
\hline
\end{tabular}

$\alpha_{1}$, IFN- $\alpha_{2}$, and cholera toxin B subunit (CT-B). Thus, using $\left[{ }^{3} \mathrm{H}\right]$ LKEKK, we demonstrated the existence of a non-protein receptor common for TM- $\alpha_{1}$, IFN- $\alpha_{2}$, and CT-B on human T lymphocytes, and rat intestine epithelial cell membranes. We suggested that this receptor could be the cholera toxin receptor, as is known, is a GM1-ganglioside $[9,12]$.

To prove this hypothesis, in this study we have prepared 125I-labeled CT-B and investigated its interaction with rat IEC-6 intestinal epithelial cells in the absence and in the presence of unlabeled TM- $\alpha_{1}$, IFN- $\alpha_{2}$, peptides LKEKK and KKEKL.

\section{Material and methods}

\subsection{Chemicals}

$\mathrm{Na}{ }^{125}$ I $\left(2 \times 10^{6} \mathrm{Ci} / \mathrm{M}\right.$ specific activity $)$ was from Russian Scientific Center "Applied Chemistry" (St. Petersburg, Russia). All media, sera for culturing cells, $1,3,4,6$-tetra-chloro- $3 \alpha, 6 \alpha$ diphenilglicoluril (Iodogen), and other chemicals were obtained from Sigma (St. Louis, MO).

\subsection{Peptides and proteins}

Human thymosin- $\alpha_{1}$ were obtained from Immunodiagnostic AG (Germany), cholera toxin B subunit was from Sigma (USA). Peptides LKEKK and KKEKL were synthesized on an Applied Bio systems Model 430A automatic synthesizer (USA) using the Boc/Bzl tactics of peptide chain elongation as described previously [24]. The peptides were purified to homogeneous state by preparative reverse-phase HPLC (Gilson chromatograph, France) on a Delta Pack C18 column, $100 \mathrm{~A}(39 \times 150 \mathrm{~mm}$, mesh size 5 $\mu \mathrm{m}$; flow rate $10 \mathrm{ml} / \mathrm{min}$, elution with $0.1 \%$ TFA, gradient of acetonitrile $10-40 \%$ in $30 \mathrm{~min}$ ). The molecular masses of the peptide were determined by fast atom bombardment mass spectrometric analysis (Finnigan mass spectrometer, San Jose, CA). The data of amino acid analysis (hydrolysis by $6 \mathrm{M} \mathrm{hcl,} 22 \mathrm{~h}, 110^{\circ} \mathrm{C}$; LKB 4151 Alpha Plus amino acid analyzer, Sweden) and mass spectrum analysis are presented in (Table 1).

\subsection{Preparation of ${ }^{125}$ II-labeled CT-B}

CT-B $(20 \mu \mathrm{g})$ was labeled by solid phase oxidation method using Na125I (1 mci) and Iodogen [21]. The labeled protein was purified by gel filtration on Sephadex G-25 $(0.9 \times 10 \mathrm{~cm}$ column, $50 \mathrm{~mm}$ phosphate buffer, ph 7.4).

\subsection{Cell culture}

Rat IEC-6 and human Caco-2 intestinal epithelial cell lines were kindly provided by Moscow Research Epidemiology and Microbiology Institute. Cells were maintained at $37^{\circ} \mathrm{C}$ in $5 \% \mathrm{CO} 2$ in DMEM medium supplemented with $10 \%$ fetal bovine serum. All experiments were performed with cells which were in between 15 and 25 passages. Cells in exponential growth phase used for all experiments.

\subsection{Binding assay}

The binding of 125I-labeled CT-B to riec- 6 cells was assayed in $1 \mathrm{ml}$ of RPMI-1640 medium, containing $10 \mathrm{~mm}$ Hepes, $20 \mathrm{~mm}$ nan 3 and $0.6 \mathrm{mg} / \mathrm{ml}$ PMSF (ph 7.4). As following: $100 \mu \mathrm{l}$ labeled protein (concentration range $10^{-10}-10^{-7} \mathrm{M}$, each concentration point in triplicate) plus $100 \mu \mathrm{l}$ medium (for total binding) or $10^{-4} \mathrm{M}$ unlabeled peptide (for nonspecific binding) were added to $800^{\mu} 1$ cell suspension $\left(10^{6}\right.$ cells) and incubated at $4^{\circ} \mathrm{C}$ for $40 \mathrm{~min}$. Then the samples were filtered through Whatman GF/A glass fiber filters to separate cell-bound labeled protein from non-bound (free) one. Filters were washed three times with 5 $\mathrm{ml}$ ice-cold saline. Radioactivity was counted using Mini-Gamma counter (LKB, Sweden). The specific binding of ${ }^{125}$ I-labeled CT$\mathrm{B}$ to cells was determined as the difference between total and nonspecific binding that was measured in the presence of $10^{-4}$ M unlabeled protein. The specific binding of ${ }^{125}$ I-labeled CT-B to cells was further characterized by the equilibrium dissociation constant $\mathrm{K}_{d}$, To determine $\mathrm{K}_{d}$, the ratio between molar concentrations of the bound (B) and free (F) labeled protein was plotted against molar concentration of the bound labeled protein (B) [20].

\subsection{Competition assay}

To estimate the inhibitory effects of TM- $\alpha_{1}$, IFN- $\alpha_{2}$, peptides LKEKK and KKEKL, the cells $\left(10^{6} / \mathrm{ml}\right)$ were incubated with $5 \mathrm{~nm}$ labeled CT-B and one of the tested ligands (concentration range, $10^{-12} 10^{-5} \mathrm{M}$; three measurements for each concentration) as described above. The inhibition constant $\left(\mathrm{K}_{i}\right)$ was calculated using the formula: $\mathrm{K}_{i}=\left[\mathrm{IC}_{50}\right] /\left(1+[\mathrm{L}] / \mathrm{K}_{d}\right)$, where $[\mathrm{L}]$ is the ${ }^{125} \mathrm{I}$ labeled CT-B molar concentration; $\mathrm{K}_{d}$ is the equilibrium dissociation constant of the 125I-labeled CT-B-receptor complex; $\mathrm{IC}_{50}$ is the concentration of unlabeled ligand causing 50\% inhibition of the labeled protein specific binding [3]. $\mathrm{IC}_{50}$ was determined graphically from the inhibition plots. The value of $\mathrm{K}_{d}$ was determined as described above. The data are presented as the means \pm SEM of at least three independent experiments.

\subsection{Fractionation of riec- 6 cells}

Cells were resuspended in $10 \mathrm{~mm}$ Tris-hcl buffer, ph 7.5, containing $1 \mathrm{~mm}$ mgcl2, $1 \mathrm{~mm}$ DTT, $5 \mu \mathrm{m}$ pepstatin A, $50 \mu \mathrm{m}$ PMSF, $10 \mu \mathrm{m}$ soybean trypsin inhibitor, and $1 \mathrm{~mm}$ benzamidine. The resulting suspension $\left(5 \times 10^{8}\right.$ cells $\left./ \mathrm{ml}\right)$ was homogenized on an ice-cold bath, and the homogenate was centrifuged at $100000 \mathrm{~g}$ (10 min, $4^{\circ} \mathrm{C}$ ). Supernatants were sampled, and sediments were resuspended in equal volumes of the buffer solution. The supernatants were used to determine the activity of sgc, and resus- 
pended sediments - to determine the activity of AC and pgc.

\subsection{Nitric oxide assay}

In oxygenated medium, $\mathrm{NO}$ is rapidly oxidized to NO2 . Therefore, riec- 6 cell media was collected in $1.5 \mathrm{ml}$ tubes and the samples were assayed in duplicate for nitrite (NO2 ) using a chemiluminescence nitric oxide analyzer as previously described (Chicoine et al., 2004). Briefly, $50 \mu 1$ of sample were placed in a reaction chamber containing a mixture of sodium iodide (nai) in glacial acetic acid to reduce NO2 to NO. The NO gas was carried into the NO-analyzer by a constant flow of Helium gas. The analyzer was calibrated with a nano2 standard curve.

\subsection{Nitric oxide assay}

The adenylate cyclase (AC) activity was determined with $\left[\alpha^{-32} \mathrm{P}\right.$ ]ATP according to the method described earlier [22]. Isoproterenol activating AC via $\beta$-adrenergic receptors was taken as a positive control [30]. The enzyme activity was expressed in nanomoles of catp formed in $10 \mathrm{~min}$ per $1 \mathrm{mg}$ of the membrane protein.

The guanylate cyclase (sgc and pgc) activity was measured by monitoring the conversion of $\left[\alpha^{-32} \mathrm{P}\right] \mathrm{GTP}$ to $\left[{ }^{32} \mathrm{P}\right] \operatorname{cgmp}$; the product was isolated by precipitation with zinc carbonate and chromatography on a column of aluminum oxide $[23,26]$. The enzyme activity was expressed as the amount of cgmp produced in $10 \mathrm{~min}$ (in nano moles per $1 \mathrm{mg}$ protein). The protein concentration was determined by the Lowry method [14] using bovine serum albumin as a standard. Statistical study was performed by the Student's t-test.

\section{Results}

The main characteristics of the synthesized peptides are given in (Table 1).

\subsection{Binding of ${ }^{125}$ I-labeled CT-B to riec- 6 cells}

We found that ${ }^{125}$ I-labeled CT-B bound specifically to riec- 6 cells. The receptor-labeled CT-B complex reached dynamic equilibrium after $\sim 40 \mathrm{~min}$ of incubation at $4^{\circ} \mathrm{C}$ and remained in this state for at least two hours. Therefore, to assess the equilibrium dissociation constant $\left(\mathrm{K}_{d}\right)$ for the labeled protein binding to riec6 cells, the reaction was carried out for $40 \mathrm{~min}$. The nonspecific binding of ${ }^{125}$ I-labeled CT-B under these conditions was $11.3 \pm$ $0.9 \%$ of its total binding. The Scatchard plot characterizing the specific binding of ${ }^{125}$ I-labeled CT-B to riec- 6 cells is shown in (Figure 2) The linear character of the plot indicates that there is one type of binding sites for labeled protein on the cells, $\mathrm{K}_{d}=3.7$ $\pm 0.3 \mathrm{~nm}$.

To characterize the specificity of the ${ }^{125}$ I-labeled CT-B binding to riec- 6 cells, unlabeled TM- $\alpha_{1}$, IFN- $\alpha_{2}$, the peptide LKEKK, and the peptide KKEKL with the reverse sequence were tested as potential competitors. The $\mathrm{K}_{i}$ values (Table 2) demonstrated strong inhibitory capacity of TM- $\alpha_{1}$, IFN- $\alpha_{2}$, and the peptide LKEKK $\left(\mathrm{K}_{i}=1.5 \pm 0.3,1.0 \pm 0.3,2.0 \pm 0.5\right)$, whereas the peptide KKEKL did not inhibit the ${ }^{125}$ I-labeled CT-B binding $\left(\mathrm{K}_{i}>\right.$ $10 \mu \mathrm{m}$ ), indicating a high specificity of TM- $\alpha_{1}$, IFN- $\alpha_{2}$, and the peptide LKEKK binding. Thus, TM- $\alpha_{1}$, IFN- $\alpha_{2}$, and the peptide

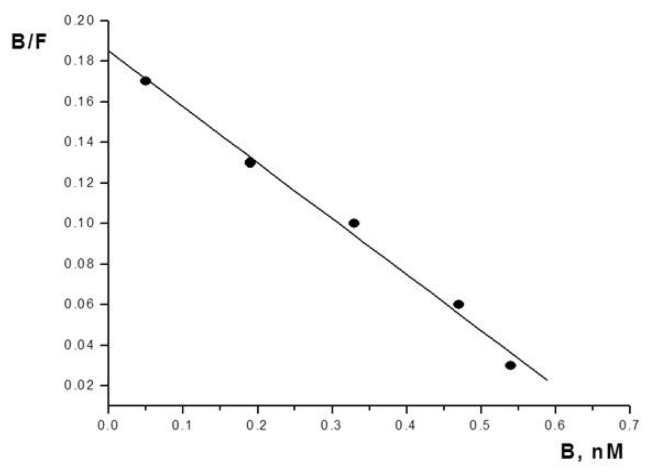

Figure 2: Scat chard analysis of the specific binding of ${ }^{125} \mathrm{I}$ labeled CT-B to of rIEC- 6 cells. B and F molar concentrations of bound and free labeled protein, respectively.

Table 2 Inhibition of ${ }^{125}$ I-labeled CT-B specific binding to rIEC- 6 cells by unlabeled ligands

\begin{tabular}{|l|l|l|}
\hline Ligand & IC $_{50}(\mathbf{n M})$ & $\mathbf{K}_{i}(\mathbf{n M})$ \\
\hline IFN- $\alpha_{2}$ & $1.5 \pm 0.2$ & $1.0 \pm 0.2$ \\
\hline TM- $\alpha_{1}$ & $2.3 \pm 0.3$ & $1.5 \pm 0.3$ \\
\hline LKEKK & $3.0 \pm 0.2$ & $2.0 \pm 0.3$ \\
\hline KKEKL & $>100$ & $>100$ \\
\hline
\end{tabular}

Note: Values are averages (means \pm SEM) of at least three independent experiments performed in triplicate. Assays conditions are described under Materials and Methods.

LKEKK bind with high affinity and specificity to the CT-B receptor on riec- 6 cells.

\subsection{Effects of CT-B, peptides LKEKK and KKEKL on the nitric oxide production in riec- 6 cells}

The results presented in (Table 3) show that CT-B and the peptide LKEKK at concentrations of 10 - $1000 \mathrm{nM}$ enhanced NO production (measured as $\mathrm{NO}_{2}^{-}$) in a dose-dependent manner. The enhancement leveled off at the peptide or CT-B concentration of $100 \mathrm{~nm}$. The peptide KKEKL was inactive.

Table 3 Effects of CT-B, peptides LKEKK and KKEKL on N0 production by rIEC- 6 cells

\begin{tabular}{|l|l|l|l|}
\hline \multirow{2}{*}{ Ligand (nM) } & \multicolumn{3}{|c|}{$\begin{array}{c}\text { Level of } \mathrm{NO}_{2}^{-} \text {(nmol of NO2/mL } \\
\text { medium } \pm \text { SEM) }\end{array}$} \\
\cline { 2 - 4 } & CT-B & LKEKK & KKEKL \\
\hline Control & \multicolumn{3}{|c|}{$16 \pm 3$} \\
\hline 0.1 & $14 \pm 3$ & $16 \pm 2$ & $17 \pm 3$ \\
\hline 1 & $15 \pm 2$ & $18 \pm 4$ & $14 \pm 3$ \\
\hline 10 & $20 \pm 3$ & $19 \pm 3$ & $16 \pm 4$ \\
\hline 100 & $28 \pm 3^{*}$ & $26 \pm 2^{*}$ & $18 \pm 3$ \\
\hline 1000 & $29 \pm 3^{*}$ & $27 \pm 3^{*}$ & $15 \pm 3$ \\
\hline
\end{tabular}

* Significant differences between experience and control $(\mathrm{P}<0.05)$. 
Effects of CT-B, peptides LKEKK and KKEKL on the sGC and pGC activity of rIEC-6 cells

\begin{tabular}{|l|l|l|l|l|l|l|}
\hline \multirow{2}{*}{ Ligand (nM) } & \multicolumn{2}{|c|}{ Guanylate cyclase activity (nmoles of cGMP per 1 mg protein in 10 min \pm SEM) } \\
\cline { 2 - 6 } & \multicolumn{3}{|c|}{ SGC } & \multicolumn{3}{c|}{ pGC } \\
\cline { 2 - 6 } & CT-B & LKEKK & KKEKL & CT-B & LKEKK & KKEKL \\
\hline Control & \multicolumn{3}{|c|}{$0.9 \pm 0.1$} & \multicolumn{3}{c|}{$1.5 \pm 0.2$} \\
\hline 1 & $0.8 \pm 0.2$ & $0.9 \pm 0.2$ & $1.0 \pm 0.2$ & $1.6 \pm 0.2$ & $1.6 \pm 0.2$ & $1.4 \pm 0.2$ \\
\hline 10 & $1.2 \pm 0.2^{*}$ & $1.3 \pm 0.2^{*}$ & $0.8 \pm 0.3$ & $1.5 \pm 0.3$ & $1.6 \pm 0.2$ & $1.5 \pm 0.3$ \\
\hline 50 & $1.5 \pm 0.3^{*}$ & $1.4 \pm 0.3^{*}$ & $0.9 \pm 0.2$ & $1.6 \pm 0.2$ & $1.5 \pm 0.2$ & $1.5 \pm 0.2$ \\
\hline 100 & $1.7 \pm 0.3^{*}$ & $1.5 \pm 0.3^{*}$ & $0.9 \pm 0.2$ & $1.4 \pm 0.3$ & $1.6 \pm 0.3$ & $1.4 \pm 0.3$ \\
\hline 1000 & $1.6 \pm 0.4^{*}$ & $1.5 \pm 0.3^{*}$ & $0.9 \pm 0.3$ & $1.6 \pm 0.2$ & $1.7 \pm 0.2$ & $1.8 \pm 0.3$ \\
\hline
\end{tabular}

* Significant differences between experience and control $(\mathrm{P}<0.05)$.

Table 5 Effects of CT-B, isoproterinol, peptides LKEKK and KKEKL on the AC activity of rIEC- 6 cell membranes

\begin{tabular}{|l|l|l|l|l|}
\hline $\begin{array}{l}\text { Concentr- } \\
\text {-ation of } \\
\text { compound } \\
\text { (nM) }\end{array}$ & $\begin{array}{l}\text { Adenylate cyclase activity } \\
\text { (nmoles of cAMP per 1 mg protein } \\
\text { in 10 min) }\end{array}$ \\
\cline { 2 - 5 } & CT-B & LKEKK & KKEKL & $\begin{array}{l}\text { Isopro } \\
\text { terinol }\end{array}$ \\
\hline 0 & \multicolumn{4}{|c|}{$1.8 \pm 0.2$} \\
\hline 0.1 & $1.9 \pm 0.3$ & $2.0 \pm 0.3$ & $1.9 \pm 0.2$ & $1.8 \pm 0.2$ \\
\hline 1 & $1.8 \pm 0.2$ & $1.9 \pm 0.4$ & $1.9 \pm 0.3$ & $2.2 \pm 0.3$ \\
\hline 10 & $1.9 \pm 0.2$ & $1.9 \pm 0.2$ & $1.7 \pm 0.2$ & $2.4 \pm 0.2$ \\
\hline 100 & $1.7 \pm 0.3$ & $1.8 \pm 0.3$ & $1.8 \pm 0.2$ & $2.8 \pm 0.3$ \\
\hline 1000 & $1.9 \pm 0.2$ & $1.9 \pm 0.2$ & $1.9 \pm 0.3$ & $3.2 \pm 0.4$ \\
\hline
\end{tabular}

6.3 Effects of CT-B, peptides LKEKK and KKEKL on the AC, sgc, and pgc activity of riec- 6 cells

The results presented in (Table 4) show that CT-B and the peptide LKEKK at concentrations of 10 - $1000 \mathrm{nM}$ increased in a dose-dependent manner the sgc activity in riec- 6 cells, but did not affect the pgc activity as vell as the AC activity (Table 5). The peptide KKEKL was inactive. Thus, the activating action of CT-B and the peptide LKEKK on sgc was specific and dose-dependent.

\section{Discussion}

Cholera toxin (CT) is the soluble toxin secreted by the Gram negative bacteria Vibrio cholerae. CT is an $84 \mathrm{kd}$ protein made up of two major subunits, CT-A and CT-B [29]. The CT-A subunit is responsible for the disease phenotype while CT-B provides a vehicle to deliver CT-A to target cells. CT-A is a $28 \mathrm{kd}$ subunit consisting of two primary domains, CT-A1 and CT-A2, with the toxin activity residing in the former and the latter acting as an anchor into the CT-B subunit [29]. CT-B forms a ring-like structure composed of five CT-B monomers. Each monomer is a nontoxic protein consisting of 103 amino acid residues (Lai, 1977) and binding to the monosialotetrahexosylganglioside
(GM1a, Gal $\beta 3$ GalNAc $\beta 4$ (Neu5Ac $\alpha 3$ ) Gal $\beta 4$ GlcCer) that is broadly distributed in a variety of cell types including epithelial cells of the gut $[4,9,12]$.

CT-B is now viewed as a promising immune modulating and anti inflammatory agent. Recombinant CT-B has been recently found to suppress immunopathological reactions in allergy and autoimmune diseases to stimulate humoral immunity and to induce anti inflammatory responses in vivo, in particular, to mitigate the intestinal inflammation of Crohn's disease in mice and humans $[25,29,2,28]$. Since CT-B can prevent infection but also autoimmune reactions, the question is how these two apparently opposite immune reactions can be achieved by the same protein. Currently, there is no answer to this question.

The results of this study show that 125I-labeled CT-B binds with high affinity to riec- 6 cells $\left(\mathrm{K}_{d}=3.7 \mathrm{~nm}\right.$, Figure 2 ), and unlabeled TM- $\alpha_{1}$, IFN- $\alpha_{2}$, the peptide LKEKK inhibit its binding by $100 \%$ (Figure 3, Table 2). Previously, we showed that [3H]LKEKK binds with high affinity to non-protein receptor on donor blood $\mathrm{T}$ lymphocytes, and on rat intestine epithelial cell membranes $[16,17]$. In both cases, the labeled peptide binding was competitively inhibited by unlabeled TM- $\alpha_{1}$, IFN- $\alpha_{2}$, and CT-B. These data, as well as the fact that cholera toxin has no receptors other than GM1-ganglioside, allow us to conclude that GM1-ganglioside is the receptor common for TM- $\alpha_{1}$, IFN- $\alpha_{2}$, and the peptide LKEKK. The data in (Tables 3-5) show that CT-B and the peptide: LKEKK at concentrations of $10-1000 \mathrm{~nm}$ increased in a dose-dependent manner the nitric oxide (NO) production and the soluble guanylate cyclase (sgc) activity in riec-6 cells.

Nitric oxide (NO) is the principal inhibitory neurotransmitter in the gut, endothelial-derived NO is involved in the local regulation of mucosal blood flow and inflammatory-derived NO is involved in the loss of mucosal integrity $[27,1]$. Increased production of NO and subsequent local cytotoxicity to mucosal epithelial cells has been proposed as one of the putative mechanisms in the development of necrotizing enterocolitis (NEC) [6]. NO is synthesized from L-arginine by NO synthase (NOS), of which there are three isoforms inducible NOS (inos), endothelial NOS (enos) and neuronal NOS (nnos) [15]. Of the three isoforms of NOS described, inos is not constitutively expressed, but induced at high 


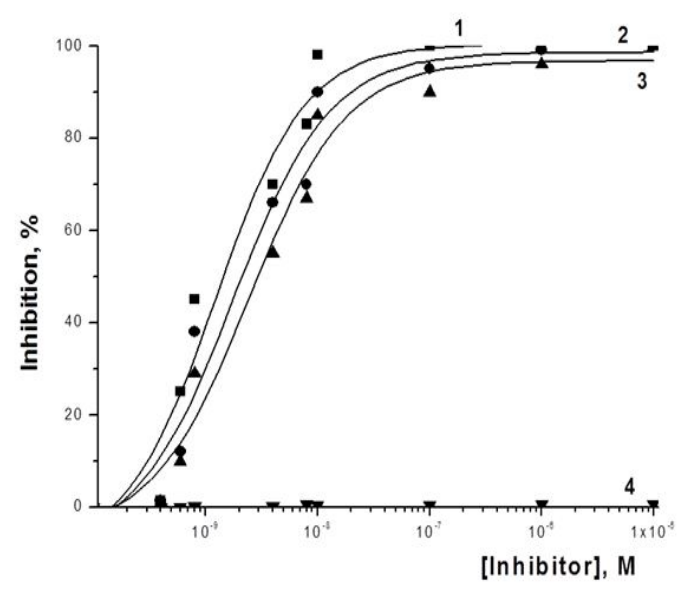

Figure 3: SInhibition of ${ }^{125}$ I-labeled CT-B specific binding to rIEC- 6 cells by unlabeled IFN- $\alpha_{2}$ (1), TM- $\alpha_{1}$ (2), peptides LKEKK (3) and KKEKL (4).

levels during inflammation resulting in relatively high levels of NO production [6]. The role of inos-derived NO in the pathogenesis of NEC was first described by Ford and colleagues who demonstrated elevated inos expression in resected human NEC tissue compared to non-NEC control tissue [10]. In experimental models of NEC, the inhibition of inos has been found to attenuate inflammatory intestinal injury $[7,11,8]$.

According to the results of this work, CT-B and the peptide: LKEKK increased in a dose-dependent manner the sgc activity in riec- 6 cells. Sgc, a heterodimer consisting of $\alpha$ and $\beta$ subunits, which is activated by the direct interaction of NO with the heme of the $\beta$ subunit [13]. There is conclusive evidence that effect of low concentrations of NO is cgmp dependent $[18,19]$. These authors measured the levels of intracellular cgmp in CD4+ T cells cultured in the presence of graded concentrations of NOC-18. Cgmp concentration was significantly elevated by $5 \mu \mathrm{m}$ and $10 \mu \mathrm{m}$ of NOC-18; this amount declined to the control level at $100 \mu \mathrm{m}$ of NOC-18. These results strongly indicate that the enhancing effect of low concentrations of NO is mediated by cgmp. The pattern of cgmp elevation closely correlated with the enhanced cell activation by NO. Our data also suggest that low levels of NO activate sgc.

As we mentioned above, CT-B has a high potential as an immune modulatory and anti-inflammatory agent. In this regard, the study of the activity of the peptide LKEKK capable of binding to GM1-ganglioside and activating sgc is of great interest.

\section{Conclusion}

The results of the present study show that TM- $\alpha_{1}$, INF- $\alpha_{2}$, and the synthetic peptide LKEKK that corresponds to residues 1620 in TM- $\alpha_{1}$ and 131-135 in IFN- $\alpha_{2}$ bind with high affinity and specificity to cholera toxin receptor on rat IEC-6 intestinal epithelial cells. The CT-B and peptide LKEKK binding to the receptor leads to an increase in activity of soluble guanylate cyclase. Residues 16-20 in TM- $\alpha_{1}$ and 131-135 in IFN- $\alpha_{2}$ are involved in binding to the receptor.

\section{Acknowledgement}

This study was funded by the Russian Foundation for Basic Research (Grant No. 14-04-00177) and Fundamental Research Program of the Presidium of RAS "Molecular and Cell Biology" (Head of the project Lipkin VM).

\subsection{Declaration of interest}

There is no conflict of interest that could be perceived as prejudicing the impartiality of the research reported.

\section{References}

1. Alican I, Kubes P. A critical role for nitric oxide in intestinal barrier function and dysfunction. Am J Physiol. 1996;270(2 Pt 1): G225-G237.

2. Baldauf KJ, Royal JM, Hamorsky KT, Matoba N. Cholera toxin B: one subunit with many pharmaceutical applications. Toxins. 2015;7(3):974-996. Doi: 10.3390/toxins7030974

3. Cheng YC, Prusoff W. Relationship between the inhibition constant (K1) and the concentration of inhibitor which causes 50 percent inhibition (I50) of an enzymatic reaction. Biochem. Pharmacol. 1973;22(23):3099-3108.

4. Chester MA. IUPAC-IUB joint commission on biochemical nomenclature (JCBN) nomenclature of glycolipids. Eur J Biochem. 1998;257(2):293-298.

5. Chicoine LG, Paffett ML, Young, TL, Nelin LD. Arginase inhibition increases nitric oxide production in bovine pulmonary arterial endothelial cells. Am J Physiol Lung Cell Mol Physiol. 2004;287(1):L60-L68. Doi: 10.1152/ajplung.00194.2003

6. Chokshi NK, Guner YS, Hunter CJ, Upperman JS, Grishin A, Ford HR. The role of nitric oxide in intestinal epithelial injury and restitution in neonatal necrotizing enterocolitis. Semin Perinatol. 2008;32(2):92-99. Doi: 10.1053/j.semperi.2008.01.002

7. Ciftçi I, Dilsiz A, Aktan TM, Gürbilek M, Duman S. Effects of nitric oxide synthase inhibition on intestinal damage in rats with experimental necrotizing enterocolitis. Eur J Pediatr Surg. 2004;14(6):398-403. Doi: 10.1055/s-2004-821105

8. Cintra AE, Martins JL, Patrício FR, Higa EM, Montero EF. Nitric oxide levels in the intestines of mice submitted to ischemia and reperfusion: L-arginine effects. Transplant Proc. 2008;40(3):830-835. Doi: 10.1016/j.transproceed.2008.02.044

9. Cuatrecasas P. Gangliosides and membrane receptors for cholera toxin. Biochemistry. 1973;12(18):3558-3566. Doi: 10.1021/bi00742a032

10. Ford H, Watkins S, Reblock K, Rowe M. The role of inflammatory cytokines and nitric oxide in the pathogenesis of necrotizing enterocolitis. J Pediatr Surg. 1997;32(2):275-282. 
11. Giannone PJ, Schanbacher BL, Bauer JA, Reber KM. Effects of prenatal lipopolysaccharide exposure on epithelial development and function in newborn rat intestine. J Pediatr Gastroenterol Nutr. 2006;43(2):284-290. Doi: 10.1097/01.mpg.0000232572.56397.d6

12. Holmgren J, Lönnroth I, Svennerholm L. Tissue receptor for cholera EXOTOXIN: Postulated structure from studies with G(M1) ganglioside and related glycolipids. Infect Immun. 1973;8(2):208-214.

13. Kots AY, Martin E, Sharina IG, Murad F. A short history of cGMP, guanylyl cyclases, and cGMP-dependent protein kinases. Handb Exp Pharmacol. 2009;191:1-14.

14. Lowry OH, Rosebbrough NJ, Farr OL, Randal RJ. Protein measurement with the Folin phenol reagent. J Biol Chem. 1951;193(1):265-275.

15. Moncada S. Nitric oxide in the vasculature: physiology and pathophysiology. Ann NY Acad Sci. 1997;811:60-67.

16. Navolotskaya EV, Zinchenko DV, Zolotarev YA, Kolobov AA, Lipkin VM. Binding of synthetic LKEKK peptide to human T-lymphocytes. Biochemistry (Moscow). 2016;81(8):871-875. Doi: 10.1134/S0006297916080071

17. Navolotskaya EV, Sadovnikov VB, Zinchenko DV, Vladimirov VI, Zolotarev YA, Kolobov AA. The LKEKK synthetic peptide as a ligand of rat intestinal epithelial cell membranes. Russ J Bioorg Chem. 2016;42:479-483. DOi:10.1134/S1068162016050137

18. Niedbala W, Wei XQ, Piedrafita D, Xu D, Liew FY. Effects of nitric oxide on the induction and differentiation of Th1 cells. Eur J Immunol. 1999;29(8):2498-2505.

19. Niedbala W, Cai B, Liew FY. Role of nitric oxide in the regulation of $\mathrm{T}$ cell functions. Ann. Rheumatic Dis. 2006;65(suppl 3):37-40. Doi: 10.1136/ard.2006.058446

20. Pennock BE. A calculator for finding binding parameters from a Scatchard plot. Anal Biochem. 1973;56(1):306-309.

21. Salacinski PRP, McLean C, Sykes JEC, ClementJones VV, Lowry PJ. Iodination of proteins, glycoproteins, and peptides using a solid-phase oxidizing agent, 1,3,4,6tetrachloro- $3 \alpha, 6 \alpha$-diphenyl glycoluril (Iodogen). Anal Biochem. 1981;117(1):136-146.

22. Saltarelli, D, Fischer, S, Gacon G. Modulation of adenylate cyclase by guanine nucleotides and Kirsten sarcoma virus mediated transformation. Biochem Biophys Res Commun. 1985;127(1):318-325.

23. Schultz G, Buhme E. Methods of Enzymatic Analysis. Germany; Verlag Chemie, Weinheim: 1984.

24. Schnolzer M, Alewood P, Jones A, Alewood D, Kent SB. In situ neutralization in Boc-chemistry solid phase peptide synthesis. Rapid, high yield assembly of difficult sequences. Int $\mathrm{J}$ Peptide Protein Res. 1992;40(3-4):180-193.

25. Smits $\mathrm{HH}$, Gloudemans $\mathrm{AK}$, van Nimwegen $\mathrm{M}$, Willart MA, Soullie T, Muskens F, et. al. Cholera toxin B suppresses allergic inflammation through induction of secretory IgA. Mucosal Immunol. 2009;2(4):331-339. Doi: 10.1038/mi.2009.16

26. Southam E. Measurement of cGMP and soluble guanylyl cyclase activity. Curr. Protoc. Toxicol. 2001.

27. Stark ME, Szurszewski JH. Role of nitric oxide in gastrointestinal and hepatic function and disease. Gastroenterology. 1992;103(6):1928-1949.

28. Stratmann T. Cholera Toxin Subunit B as Adjuvant-An Accelerator in Protective Immunity and a Break in Autoimmunity. Vaccines (Basel). 2004;3(3):579-596. Doi: 10.3390/vaccines3030579

29. Sun JB, Czerkinsky C, Holmgren J. Mucosally induced immunological tolerance, regulatory $\mathrm{T}$ cells and the adjuvant effect by cholera toxin B subunit. Scand J Immunol. 2010;7(1):1-11. Doi: 10.1111/j.1365-3083.2009.02321.x

30. Wrenn SM Jr, Homcy CJ. Photoaffinity label for the beta-adrenergic receptor: synthesis and effects on isoproterenolstimulated adenylate cyclase. Proc Natl Acad Sci USA. 1980;77(8):4449-4453.

31. Zav'yalov VP, Navolotskaya EV, Abramov VV, Galaktionov VG, Isaev IS, Kaurov OA, et. al. The octapeptide corresponding to the region of the highest homology between a-interferon and thymosin-a1 effectively competes with both cytokines for common high-affinity receptors on murine thymocytes. FEBS Lett. 1991;278:187-189.

32. Zav'yalov VP, Navolotskaya EV, Vasilenko RN, Abramov VM, Volodina EY, Roslovvtseva OA, et. Al. The sequence 130-137 of human interferon-a2 is involved in the competition of interferon, prothymosin a and cholera toxin B subunit for common receptors on human fibroblasts. Mol. Immunol. 1995;32(6):425-431. Doi: 10.1016/0161-5890(94)00161-S 